of crop plants, domestic animals and human beings.

The other important method of returning organic matter to the soil, namely, the practice of green manuring, is approved of, if the crops grown for this purpose are cut and used to provide material for composting, leaving only the root system to decay in the ground and thereby considerably reducing the burden on the soil.

R. O. Whyte.

\title{
COLONIAL ADMINISTRATION
}

Democratise the Empire

A Policy for Colonial Change. By W. M. Macmillan. (The Democratic Order, No. 6.) Pp. 64. (London: Kegan Paul and Co., Ltd., 1941.) ls. net.

$\mathrm{O}^{\mathrm{N}}$ the first page of this arresting, and indeed, challenging pamphlet, the author says, "on the face of it, Empire, the government of weaker peoples by a power outside themselves, is the very antithesis of the Democracy for which we stand". The truth, of course, is that in a too rapid development towards independence there is great danger lest a country, lately brought within the orbit of mod. ern civilization, be controlled by the well-educated few who will not be subject to the checks of an informed and articulate population. In such checks lies the real strength of a democratic constitution.

Prof. Macmillan recognizes this, but he maintains that the pace has been too slow and that British Colonial policy has suffered from laisserfaire, particularly in the economic sphere, one on which he is very competent to speak and on which he has many interesting things to say. He praises the 'tripartite Co-operation' of the cotton-growing enterprise in the Sudan, whereby the Government met the cost of a large-scale irrigation scheme, the Sudan Plantations Syndicate provides expert management and the peasants receive a fixed proportion of the price of the cotton when sold. This principle, he says, might be applied to mining, public utility services, plantations, and so on. Some of the profits might be returned to the people in the shape of improved welfare services.

There are many who would also like to see experiments made in 'co-operation' (in the technical sense) especially among the inhabitants of the rural areas, combined with a scheme for the education and development of the people based on their indigenous culture and traditional way of life. Such experiments might well follow the suggestions contained in a memorandum emanating from the Colonial Office Advisory Committee and entitled "The Education of African Communities".

It is impossible in a short article to discuss the many aspects of the Colonial problem upon which Prof. Macmillan touches. This small book is packed with interesting and suggestive comments.

The main theme, however, is political structure. $\mathrm{He}$ is somewhat critical of 'Indirect Rule'. which is now an accepted principle of government in some of our Colonies. He recognizes its value as a form of local government, provided that it is not considered "as the last word in the Government of any people". In due course the people will rightly demand control of the non-native supreme authority, and he asks what machinery we can provide but representative institutions.

The real justification for 'Indirect Rule' is that it represents an important educational stage. In its present form it is a means and not an end in itself. Moreover, 'Indirect Rule', adopted in many African Colonies, cannot be applied to such Colonies as the West Indies, where tribal tradition and authority do not exist.

If 'Indirect Rule' is to be not merely a temporary expedient but also to supply the basis of future Government, there must be clear vision of the end in view and the means for attaining it. It is for the British Government to see that the successive stages in each Colony are reached as soon as local conditions make such advance possible. That the British Government is prepared to shoulder this responsibility is indicated by the steps already taken to make a survey in each area of the political framework, economic possibilities and the various human problems involved, as a first step towards formulating a progressive policy. The immediate goal appears to be gradually to develop, from indigenous institutions, forms of local government embracing far larger areas and sections of the population than those from which they have sprung, and federated under a central council which derives its authority from them. The people themselves will eventually have to decide in the light of experience gained during this educational period, to what extent modifications suggested by European forms of democracy may be desirable.

It would be out of place here to mention international problems involved in our own Colonial policy, but there is one outstanding difficulty within our boundaries which must be faced. It is that of reconciling the natural aspirations of the African population with the claims of Europeans in areas of white settlement. The problem is one of immense difficulty, but if handled firmly and handled quickly, there is no reason why it should prove to be insoluble.

E. R. J. Hussey. 